\title{
Po końcu światów? Dystopijna podróż w czasie w opowiadaniu Shermana Alexie Odległości
}

\section{After Worlds' End? Dystopian Time Travel in Sherman Alexie's Flight}

Literackie czy filmowe obrazy tego, jak mógłby wyglądać świat, kiedy by go już nie było, czyli po swoim końcu, tworzono wielokrotnie. Ich twórców kusiły różne wyzwania: relacja z inwazji kosmitów, szaleńcze możliwości rozhulanej makabry, dydaktyczna przestroga (zarówno ekologiczna, jak i teologiczna), przeprowadzka do innej galaktyki, genialne technologie otwierające nowe światy lub makieta czegoś w rodzaju feniksa z popiołów, obdarzonego sztuczną inteligencją etc. Otóż Shermana Alexie ${ }^{1}$ nie kusił żaden z takich pomysłów.

Rdzenni mieszkańcy Ameryki koniec świata mają już zasadniczo za sobą. Jest to straszne, lecz na swój dramatyczny sposób wyzwalające, zwłaszcza dla

${ }^{1}$ Sherman Alexie jest współczesnym pisarzem amerykańskim pochodzenia indiańskiego, który należy do drugiej (młodszej) fali nurtu zwanego Native American Renaissance. Urodził się w 1966 roku na terenie rezerwatu Indian Spokane w stanie Washington. Ze strony matki pochodzi ze szczepu Spokane, ze strony ojca jego indiańska grupa etniczna to Coeur d'Alene. Dzięki stypendiom kształcił się w Gonzaga College, kolegium jezuickim, a potem w Washington State University. Jest autorem wielu opowiadań, powieści, poezji i scenariuszy filmowych. Do jego najlepiej znanych dzieł prozatorskich należą The Absolutely True Diary of a Part-Time Indian, Reservation Blues, The Business of Fancydancing oraz The Lone Ranger and Tonto Fistfight in Heaven - zbiór powiązanych ze sobą opowiadań, z którego pochodzi omawiany tutaj tekst Distances (Odlegtości). Do jego najpopularniejszych filmów należy Smoke Signals. Nurt Native American Renaissance stworzyli Amerykanie pochodzenia indiańskiego w latach siedemdziesiątych XX wieku. Zdobyli już wykształcenie wyższe, w dużym stopniu zasymilowani byli z białym społeczeństwem, ale ciągle jeszcze mieli mocną świadomość własnej odrębności, tragizmu swojej historii i złożoności synkretyzmów kulturowych. Próbowali w swoich utworach przybliżyć doświadczenie życia z tożsamością indiańską i amerykańską, poczuciem zawieszenia między kulturami, nigdy do końca nie czując się u siebie w żadnej z nich. Najważniejsi twórcy tego kręgu to: N. Scott Momaday, Louise Erdrich, Leslie Marmon Silko, Linda Hogan, James Welch, Thomas King, Gerald Viznor i Sherman Alexie. 
twórców literatury lub sztuki w ogóle. Z tego właśnie wyzwolenia, z tej perspektywy, smutnej, ale dającej możliwość widzenia inaczej, dalej, głębiej, korzysta Alexie, pisząc Odlegtości.

A więc ile światów kończy się lub już się skończyło w tym opowiadaniu?

Ten pierwszy, to ten, który kończył się w czasach indiańskiego proroka Wovoki - jego słowa przywołane są w motcie opowiadania - a czasy jego publicznej działalności to przełom lat osiemdziesiątych i dziewięćdziesiątych XIX wieku.

A oto fragmenty motta:

Wszyscy Indianie muszą tańczyć, wszędzie, ciągle tańczyć. Już niedługo na wiosnę przyszłego roku Wielki Duch idzie. Przyprowadzi wszelką zwierzynę. Pełno będzie zwierza wszędzie. Wszyscy zmarli Indianie wrócą i będą żyć od nowa. Starzy ślepi Indianie znowu widzą. Młodzi i szczęśliwi. Kiedy Wielki Duch przyjdzie w te strony, wszyscy Indianie w góry, wysoko, z dala od białych. Biali nie będą tam mogli zrobić krzywdy Indianom. A kiedy Indianie tam wysoko, wielka powódź przyjdzie i utopi wszystkich białych ludzi (...). Indianie, którzy nie tańczą, którzy nie wierzą tym słowom, skurczą się, będą nie więksi niż na wysokość stopy i tak już zostaną, skarlali, niektórzy z nich zostaną zamienieni w drewno i spaleni.

Wovoka, Mesjasz Tańca Duchów, prorok z plemienia Pajute².

Wovoka, znany też jako Jack Wilson, urodzony w 1856 roku syn szamana z plemienia Pajutów, od 14. roku życia wychowywany przez rodzinę białych protestanckich osadników, po ciężkiej chorobie, śmierci klinicznej i doświadczeniach mistycznych zaczął głosić nową synkretyczną religię pół chrześcijańską, a pół indiańską (animistyczną). Chrystus miał przyjść tym razem do Indian. Jako czerwonoskóry Jezus miał przywrócić rdzennym mieszkańcom Ameryki wolność, ziemie, bizony, sposób życia sprzed inwazji kolonialnej. Biali mieli zniknąć, a zmarli od czasu najazdu Indianie powrócić do życia. Wszystko to mogło się stać, jeśli Indianie ubłagają Jezusa Chrystusa i przyśpieszą jego przyjście przez wytrwałe rytualne tańce, w odpowiednich strojach, razem, wspólnotowo, wykonywane przede wszystkim z absolutnym oddaniem, „do upadłego" - dosłownie, bo tancerze po wielu godzinach rytmicznych ruchów padali na ziemię, a nawet wpadali w trans. Indianie powinni również całkowicie zrezygnować z używania jakichkolwiek pochodzących od białych przedmiotów, urządzeń, technologii. Taniec ten, zwany Ghost Dance (bo miał otworzyć drogę dla duchów umarłych i umożliwić spotkanie z potomkami, a stroje przypominały żałobne giezła, w których grzebano zmarłych), stał się ogromnie popularny. Nic dziwnego, że współcześni Wovoce Indianie, przymierający głodem,

${ }^{2}$ Wszystkie przytaczane tu cytaty z opowiadania Distances (Odlegtości) z tomu The Lone Ranger and Tonto Fist Fight in Heaven (Harper Perennial, New York 1994) w przekładzie autorki artykułu, Katarzyny Mroczkowskiej-Brand. 
bezdomni lub zamykani siłą do rezerwatów, z rozpaczy uchwycili się tego pięknego szalonego snu, jakim był Ghost Dance, i obietnicy powrotu ich zmarłych bliskich. Synkretyczny ruch religijny rozpoczęty przez szamana Pajutów (a jednocześnie chrześcijanina) miał pokojowy charakter. Wovoka nie nawoływał do żadnej walki czy przemocy w stosunku do białych. Tym większą tragedią i kolejną niesprawiedliwością był kończący ruch Ghost Dance w 1891 roku mord blisko 300 Indian (głównie kobiet, starców i dzieci) dokonany przez amerykańskie wojska. Strzelano do całkowicie bezbronnych cywilów nie pierwszy raz, ale to właśnie ta masakra, zwana The Wounded Knee Massacre, stała się symbolem okrucieństwa, bezsensownego przelewu krwi, haniebnego mordu na rdzennych Amerykanach. Na Wounded Knee powoływał się AIM (American Indian Movement), pod tym hasłem odbyła się próba oporu Indian z rezerwatu Pine Ridge (jeszcze w 1973 roku), o niej do dzisiaj się śpiewa Bury my Heart at Wounded Knee.

Nawiązanie do proroka Wovoki, Ghost Dance i Wounded Knee w motcie opowiadania Alexiego przypomina, że od lat siedemdziesiątych XIX do pierwszych dekad wieku XX następował finalny etap tego końca świata indiańskiego, który dotyczył istniejących jeszcze wtedy ostatnich częściowo wolnych wspólnot. Zamykaniu w rezerwatach towarzyszyły: zabieranie dzieci siłą do szkół z internatami, różne formy czystek etnicznych, kulturowych, religijnych, a także masowe wymieranie członków kolejnych plemion na choroby zakaźne przyniesione przez Europejczyków.

Tych końców indiańskich światów było już tyle od XVI do XX wieku, że nie sposób ich zliczyć, zwłaszcza gdyby brać pod uwagę nie tylko duże szczepy i plemiona, ale i pomniejsze klany i grupy etniczne czy pojedynczych wodzów, przywódców duchowych, z którymi wiązano jeszcze czasem nadzieję na cud ocalenia. Nic dziwnego, że poczucie, iż koniec indiańskiego świata już nastąpił, dominuje w tylu obrazach i narracjach. $Z$ takiej właśnie pozycji - oczywistości, że jesteśmy po końcu świata - prowadzi narrację Alexie w omawianym tu opowiadaniu. $Z$ tym, że, wbrew narzucającemu się tonowi lamentu nad grobem indiańskiego świata, pisarz korzysta z innej strategii - dekonstruuje mit powrotu do Raju Utraconego Indian, korzystając z literackiej maszyny czasu, a także z chwytów science fiction i modelu dystopii. Dekonstruuje on tenże mit nie przez zadawanie kłamu samemu proroctwu czerwonego „mesjasza”, jak bywał nazywany Wovoka, czy kpiąc z naiwności tych, którzy mu uwierzyli, tylko przez ukazywanie, jak fałszywe jest przekonanie o możliwości istnienia takich idealnych światów, takich rajów przywracanych, w jakimkolwiek czasie czy przestrzeni. Tym samym autor Odlegtości nadaje unikatowemu doświadczeniu wymiar uniwersalny.

Domyślnie pierwszym uniwersum, które zginęło prawie całkowicie, jest zbiór indiańskich światów na różnych etapach kolonizacji, zawłaszczenia, destrukcji lub przymusowej asymilacji i akulturacji. Drugim jest rzeczywistość w pewien sposób spełniająca przepowiednię Wovoki, czyli świat Indian w ich 
jak gdyby przywróconym habitacie, ale będący jednocześnie swoją własną koszmarną dystopijną parodią - to ten, w którym jeszcze żyją: narrator, Drżąca Tancerka, członkowie Rady Plemiennej i paru innych Indian, ale potem umierają lub zostają zabici przez innych Indian:

W nocy jest zimno, tak zimno, że palce mogą przymarznąć do twarzy, której się dotyka. W dzień słońce przyciska nas mocno do ziemi. Wszyscy starzy ludzie umierają, wolą utopić się we własnej wodzie niż umrzeć z pragnienia. Wszystkie ich ciała są złe, Rada Plemienna tak postanowiła. Palimy ich ciała na boisku futbolowym...

Ten świat właśnie umiera na naszych oczach, mimo że wydaje się zasilany powracającymi z jeszcze dalszej przeszłości Pra-Indianami ( „The Others” / „Inni”). To „zasilanie” jest jednak kolejnym złudzeniem, gdyż przynoszą oni wiele zniszczenia, okrucieństwa i śmierci:

Nadeszli Inni. Ci sprzed tysiąca lat, z siwymi warkoczami łamiącymi się ze starości. Przyszli ze strzałami, łukami, kamiennymi toporami i wielkimi rękami. (...) Uciekam z mojego tipi przez pole do drzewa, wspinam się na jego gałęzie, by obserwować Innych. Jeden jest wyższy od chmur, nie jedzie konno, biegnie przez kurz, szybciej niż moja pamięć.

Kolejny istniejący równolegle czasowo i przestrzennie jest „świat po końcu świata", czas po apokalipsie nuklearnej lub czymś w tym rodzaju, po zagładzie znanego nam globu ziemskiego. Podobieństwo opisywanej sytuacji do świata po wybuchu bomby atomowej zasugerowane jest objawami choroby popromiennej u Drżącej Tancerki:

Jest jedna kobieta, którą kocham, Drżąca Tancerka, ale ona należy do Miastowych. Miastowi to Indianie z miasta, którzy przeżyli i wyprowadzili się do rezerwatów po tym, jak wszystko się rozpadło. Była ich setka, kiedy przyszli, ale większość z nich umarła od tego czasu. Teraz zostało ich ze dwanaścioro i wszyscy są chorzy. Ci poważniej chorzy wyglądają, jakby mieli z pięćset lat. Wyglądają, jakby żyli już całą wieczność i jakby zaraz mieli umrzeć. Drżąca Tancerka nie jest jeszcze chora, ale ma poparzenia i blizny na całych nogach. Kiedy tańczy wokół ogniska nocą, cała drży z bólu. (...) Czasami jej skóra złuszcza się, płatki opadają na ziemię. Czasem czuję smak kawałków jej ciała odłamujących się w moich ustach. Mają smak krwi, kurzu, żywicy, słońca.

Struktura czasowo-przestrzenna całego tekstu to wielopoziomowa, mobilna, postapokaliptyczna konstrukcja, w którą końce indiańskich światów są wpisane jako wydarzenia pierwszoplanowe, ale nie jedyne.

Nie tylko czas zwariował w świecie po końcu światów. A swoją drogą czas zwariował dosyć oryginalnie, bo jednocześnie pędzi do tyłu i do przodu, 
zawracamy do prapoczątków: jesteśmy po końcu wszystkiego i jeszcze dalej. Popsuł się również mechanizm mający cudotwórczo przywracać szczęście wolnych już od białych Indian, bo przecież wedle proroctwa Wovoki miała to być kraina powszechnego indiańskiego dobrobytu i dobrostanu. Tymczasem wszystkie postacie żyjące (a raczej dogorywające) w świecie przedstawionym tekstu cierpią i są rozpaczliwie smutne, tak jak i cały otaczający ich przerażający krajobraz (por. „Znalazłem jedną roślinę, czarny kwiat, w cieniu Tamy Małych Wodospadów. Następną znalazłem dopiero po czterdziestu latach, pomiędzy murami starego domu na wybrzeżu").

Jak się dowiadujemy, głównym zajęciem bohaterów opowiadania, w tym samego narratora, jest palenie ciał i spalanie domów. Mają w ten sposób wyeliminować wszystko, co było skażone obecnością białych lub ich rękodzieła czy wytworzonych przez nich urządzeń. Żyjący w postświecie, mającym być ich praświatem, są już podzieleni i skłóceni. Władzę chwilowo dzierżą Skóry (Skins) Indianie żyjący poza miastami, żyją jeszcze ostatni Miastowi (The Urbans), do których należała Drżąca Tancerka. Rady Plemienne już są skorumpowane:

Wczoraj wieczorem na zebraniu Rady Plemiennej Judasz Dziki But oddał naczelnikowi plemienia zegarek, który znalazł.

„Rękodzieło białego człowieka, grzech”. Powiedział naczelnik i włożył zegarek do swojej kieszeni.

Absurdalny przepis o zakazie posiadanie urządzeń pochodzących od białych jest łamany, kiedy się tylko da, bo Indianie bardzo za nimi tęsknią, jak o tym świadczy wyznanie narratora, który pod łóżkiem ukrywa małe tranzystorowe radio:

Wczoraj w nocy śniła mi się telewizja. Obudziłem się, płacząc.

(...) Poprzedniej nocy śniłem o telewizji. Obudziłem się, płacząc.

Wczoraj w nocy trzymałem $\mathrm{w}$ rękach moje radio tranzystorowe, delikatnie, jakby było żywe. Bardzo dokładnie je obejrzałem, szukając jakiejś usterki, jakiegoś wyraźnego śladu uszkodzenia. Ale niczego takiego nie było. (...)

Trzymałem w rękach radio i włączyłem je, podkręciłem głos na maksa, aż do chwili, kiedy jedynym dźwiękiem, jaki mogłem usłyszeć, był mój oddech, wdech i wydech.

Koszmar, jaki jest udziałem bohaterów opowiadania, służy, po pierwsze, pokazaniu absurdu jakichkolwiek snów o odwracaniu czasu, a także szkodliwości mitów o domniemanej uprzedniej szczęśliwości „prostego, dzikiego życia” czy o możliwości zniszczenia powiązań z inną kulturą po paruset latach wspólnej już egzystencji. Jedną z ważnych funkcji, jakie spełnia wizja horroru po końcu światów w tekście Alexiego, jest przypomnienie ponadczasowych prawd: prawdy o ludzkiej naturze, tej twardej, bezwzględnej (po końcu światów znowu 
jest wojna, jej kolejny wariant) i tej kruchej emocjonalnej (szukanie czułości w związku, nawet z umierającą już Drżącą Tancerka). Reguły gry wyznaczają przemoc i strach w każdym czasie i w każdej grupie etnicznej, lecz jednocześnie potrzeba bliskości, czułości i empatii wciąż istnieje, choć ci, którzy przeżyli, i ci, którzy umierają, skrzętnie to ukrywają.

Jest to też, a może raczej przede wszystkim, swoista „baśn”” o nieodwracalności utraty. Głównie w tym sensie, że w kontekście literatury postkolonialnej, do której to opowiadanie należy, przypominanie zaginionych i ginących już kultur oraz pokazywanie nieodwracalności tej utraty jest funkcją najważniejszą. Odlegtości spełniają tę funkcję w bardzo oryginalny sposób. Konstrukcja czasoprzestrzeni jest niezwykła: łączy praczas z postczasem, horror i dystopię, by zredukować do absurdu pomysły na przywracanie „rajów utraconych”. Owe raje są przecież apokaliptycznymi postświatami. A wszystko to stworzone, napisane, za pomocą jakże oszczędnych środków - pięć stron czegoś w rodzaju „dziennika pokładowego”, bo tak wygląda narracja (por. „Wczoraj w nocy spaliliśmy następny dom. Rada Plemienna zdecydowała, że wszystko, co ma jakikolwiek związek z białymi, musi być zniszczone").

Odkąd powstał i rozwijał się American Indian Renaissance, czyli nurt we współczesnej literaturze amerykańskiej tworzony przez Amerykanów pochodzenia indiańskiego, dominowały próby rekonstrukcji historii rdzennych mieszkańców kontynentu północnoamerykańskiego (w czasie kolonizacji i po kolonialnym zawłaszczaniu) - świat przedstawiony tych tekstów sytuował się pomiędzy rekonstrukcją a mitem. Nierzadko prezentowano swego rodzaju epikę heroiczną lub sięgano po odmiany realizmu: magicznego, psychologicznego, społecznego, ukazującego zazwyczaj alienację częściowo zasymilowanych post-Indian. Czasem też łączono realizm z groteską i czarnym humorem. Natomiast taka strategia, jaką w swoim opowiadaniu przyjął Alexie, jest wyjątkowa. Jego intencją jest wywołanie w czytelniku szoku. Dokonuje destrukcji, a nie rekonstrukcji, przy czym destrukcja wymierzona jest w fałszywe idee. Nie można przywrócić utraconych rajów, skoro ich nigdy nie było, a to, co utracone, jest utracone absolutnie.

Aby czytelnik przyjął tak gorzką pigułkę prawdy, autor zastosował mieszankę dystopii, science fiction, w tym dziennik pokładowy z postświata, podróż w czasie, absurd, groteskę, horror.

Kiedy leżę w moim tipi, udając, że śpię, pod połówkami koców z psich i kocich skór, słyszę, jak konie wybuchają. Słyszę krzyki zabieranych dzieci.

(...) Najwyższy Inny, olbrzym, zabrał Drżącą Tancerkę, przyprowadził ją potem z powrotem z wielkim brzuchem. Pachniała solą, starą krwią. Urodziła łososie, wypadały z niej z pluskiem, coraz większe łososie.

Kiedy umarła, jej dłonie krwawiły wodą morską.

(...) „Nie było żadnego dźwięku” - opowiedział mi kiedyś. „Jechałem całymi dniami i nocami i nie było żadnych samochodów, nic się nie ruszało, ani 
samolotów, ani buldożerów, ani żadnych drzew. Przeszedłem przez puste miasto z jednego krańca na drugi, zajęło mi to sekundę. Zamrugałem oczami i miasta już nie było, zostało za mną".

Słyszałem pogłoski, że krewni zmarłych mogą też zostać zabici i spaleni. Rada Plemienna zdecydowała, że to przez chorobę białych, która skaziła ich krew. To przez zegarek, który utkwił im między żebrami, idzie coraz wolniej, aż w końcu staje. Cieszę się, że moi dziadkowie i moi rodzice umarli, zanim to się stało. Cieszę się, że jestem sierotą.

Jeśli nawet nie na wszystkich czytelnikach wywrze to jednakowo silne wrażenie, to jednak trudno odmówić autorowi oryginalności, jeśli chodzi o sposób budowania obrazu świata przedstawionego i przesłania utworu. 